\title{
A seasonal diary of phytoplankton in the North Atlantic
}

\section{Christian Lindemann* and Michael A. St. John}

National Institute of Aquatic Resources, Technical University of Denmark, Charlottenlund, Denmark

\section{Edited by:}

Xabier Irigoien, King Abdullah

University for Science and

Technology, Saudi Arabia

Reviewed by:

Sergio M. Vallina, Consejo Superior de Investigaciones Cientificas, Spain Xabier Irigoien, King Abdullah

University for Science and

Technology, Saudi Arabia

*Correspondence:

Christian Lindemann, National Institute of Aquatic Resources,

Technical University of Denmark,

Jægersborg Alle 1, 2920

Charlottenlund, Denmark

e-mail: chrli@aqua.dtu.dk
In recent years new biological and physical controls have been suggested to drive phytoplankton bloom dynamics in the North Atlantic. A better understanding of the mechanisms driving primary production has potentially important implications for the understanding of the biological carbon pump, as it has for prediction of the system in climate change scenarios. However, the scientific discussion regarding this topic has generally failed to integrate the different drivers into a coherent picture, often rendering the proposed mechanisms exclusive to each other. We feel that the suggested mechanisms are not mutually exclusive, but rather complementary. Thus, moving beyond the "single mechanism" point of view, here we present an integrated conceptual model of the physical and biological controls on phytoplankton dynamics in the North Atlantic. Further we believe that the acclimation of physiological rates can play an important role in mediating phytoplankton dynamics. Thus, this view emphasizes the occurrence of multiple controls and relates their variations in impact to climate change.

Keywords: North Atlantic Ocean, phytoplankton spring bloom, abiotic and biotic controls, conceptual model, climate change

\section{INTRODUCTION}

Evidence for the impact of climate change on the structure and functioning of the marine environment is becoming increasingly common in for example the North Atlantic, a key region for carbon sequestration (Gruber et al., 2002). In this system, central to our understanding of the biological carbon pump, which is expected to be of increased importance in a high $\mathrm{CO}_{2}$ ocean (Riebesell et al., 2007), is the role of phytoplankton. In the North Atlantic phytoplankton blooms form an important feature of the annual dynamics of the phytoplankton community and can contribute significantly to carbon export (Allen et al., 2005). Different definitions of the word "bloom" have been used in scientific literature, however it is most commonly referring to as elevate phytoplankton concentrations (Smayda, 1997b). The scientific discussion around the spring bloom has traditionally (Sverdrup, 1953) and more recently (Taylor and Ferrari, 2011b) been dominated by the role of physical drivers. The conditions governing net phytoplankton growth $(r)$ over the seasonal cycle on the other hand have mostly been discussed in the context of grazing control (e.g., Banse, 1992) and food web dynamics, e.g., the PEG (Plankton Ecology Group) model (Sommer et al., 1986, 2012). The "Dilution-Recoupling-Hypothesis" (Behrenfeld, 2010) and the extended version thereof, the "Disturbance-Recovery-Hypothesis" (Behrenfeld and Boss, 2014) have highlighted the importance of grazing control on spring bloom dynamics. However, publications discussing the onset of the spring bloom have generally highlight one specific process, or as in a recent review (Behrenfeld and Boss, 2014) strongly emphasize one particular control. A more holistic understanding including the importance of the interlinked nature of the biological and physical controls requires the development of an integrated understanding of how these mechanisms act individually and in concert to influence phytoplankton dynamics. Such an understanding should not only consider physical and biological drivers, and their intertwined nature, but also the cells fundamental physiological ability to react to external pressures as for example, acclimation can play an important role in population dynamics and thus help to shape the observed patterns of growth and abundance (Bowler and Scanlan, 2014).

\section{SVERDRUP AND BEYOND}

Sverdrup's "Critical-Depth-Hypothesis" (Sverdrup, 1953) states that a phytoplankton bloom is initiated when losses including, cell respiration, sinking and grazing are compensated by the integrated light driven growth within the mixed layer, thus leading to a positive net primary production $(r)$ and an increase in phytoplankton concentration. The statement, that positive net production occurs when growth is greater than losses, is inherently true. However, Sverdrup's interpretation, that this situation coincides with the onset of thermal stratification in spring has been called into question. Criticisms can mainly be attributed to different interpretations of the original model as well as a more careful investigation of Sverdrups assumptions.

Sverdrup's first assumption is the existence of a thoroughly mixed surface layer. Typically the mixed layer depth has been defined by density approximated by the homogeneous distribution of water properties such as temperature and salinity, assuming continuous mixing. However, after convective deep winter mixing the onset of stratification can be delayed on the order of days or even longer (Marshall and Schott, 1999; Taylor and Ferrari, 2011b). During this window in time, wind mixing occurs close to the surface, while the water mass is itself still characterized by a deep layer of homogeneous water properties (Chiswell, 2011). Under these conditions the density defined mixed layer 
depth does not give an accurate representation of the actual mixing depth and surface blooms can occur in the absence of stratification (Townsend et al., 1992; Taylor and Ferrari, 2011b; Ferrari et al., 2014). Taking this physically orientated view, the effect of the interplay between wind mixing and the shutdown of deep convection for the onset of a surface bloom has been proposed in the "Convection-Shutdown-Hypothesis" (Ferrari et al., 2014). A more biologically orientated vision describing similar dynamics was put forward by Smayda (1997a), who distinguished between the roles of turbulence and stratification in controlling phytoplankton growth on a cellular and population level due to their eco-physiological impacts.

Sverdrups second assumption also relates to mixing and assumes that within the mixed surface layer the level of turbulence is strong enough to distribute plankton evenly throughout the mixed layer. Assuming homogeneous turbulent diffusion throughout a mixed layer, Huisman et al. (1999) found the existence of a window of turbulence in which phytoplankton are able to achieve positive net growth, thus bloom according to his definition. At levels of turbulence below a certain threshold, the Critical Turbulence, phytoplankton growth exceeds losses due to vertical mixing and hence a bloom can develop. On the other hand when turbulence levels become too low, cells will not be maintained in the surface layer by turbulence and will sink out of the mixed layer (Huisman et al., 2002). The "Critical-Turbulence-Hypothesis" as defined by Behrenfeld and Boss (2014) applies to active mixing instead of a densitydefined mixed layer, thus allowing the combination of these assumptions.

Sverdrup further assumed a constant loss rate, encompassing cell respiration, grazing and sinking. While he himself pointed to the fact that the impact of these variable loss terms can greatly influence the compensation depth, until recently this has largely been ignored. A number of findings have brought this assumption into question. For example, the "DisturbanceRecovery-Hypothesis" focuses on the seasonally variable top-down control. During winter, the deepening mixed layer dilutes phytoand zooplankton concentrations and due to the density dependency of grazing pressure (Landry and Hassett, 1982) lead to a reduction in grazing pressure. This process has been termed the Decoupling of phytoplankton biomass from zooplankton grazing pressure (Behrenfeld, 2010) and allows for an increase in $r$ and the standing phytoplankton stock, prior to the onset of stratification in early spring (Behrenfeld and Boss, 2014). However, importantly due to mixed layer deepening this is not evidenced as a volumetric increase in biomass. As the water column begins to stratify in early spring the ability of zooplankton to maintain themselves within the stratifying water column, leads to a Recoupling of micro-zooplankton with phytoplankton cells, thus increasing grazing pressure (Evans and Parslow, 1985; Behrenfeld and Boss, 2014). This re-stratification also has implications for carbon flux as after the shutdown of deep convection, phytoplankton cells below the depth of spring stratification are Detrained, i.e., sink out below the developing summer mixed layer and thus are lost to the deep ocean and do not contribute to the new spring bloom (Evans and Parslow, 1985; Behrenfeld and Boss, 2014). This phenomenon can potentially induce an important export to depth prior to the onset of stratification (Körtzinger et al., 2008).

Sverdrup's use of a constant loss rate over a diurnal cycle and over depth has further been criticized on physiological grounds (Smetacek and Passow, 1990). Dark respiration for example is known to be highly variable, not only with regard to species but also depending on growth conditions (Steenmann Nielsen and Hansen, 1959; Falkowski and Owens, 1980; Geider and Osborne, 1989). Within a deep mixed layer cells can experience prolonged periods of darkness, which can result in changes in dark respiration rates. Jochem (1999) found that when placed in darkness within a few days cell can reduce their respiration rate to only a few percent of their respiration rate in light. Further, most taxa can produce resting stages some of which remain photosynthetically active (McMinn and Martin, 2013). French and Hargraves (1980) estimated that a period of $12 \mathrm{~h}$ would provide enough energy to sustain some diatom resting spores for 29 days in the dark.

Yet another gap in the Sverdrup Hypothesis is the role of physiology of sinking. Species-specific sinking rates depend on cell size and shape (Smayda, 1970; Miklasz and Denny, 2010) as well as on cell density, which is strongly linked to growth conditions (Anderson and Sweeney, 1977; Bienfang et al., 1982; Brookes and Ganf, 2001) and can exhibit a response time of only a few hours (Waite et al., 1992). Huisman et al. (2002) showed that a certain level of turbulence is required to counteract cell sinking. However, for example Acuña et al. (2010) found that growing diatoms can control their density to achieve positive buoyancy und thus persist even in conditions of low turbulence. Similarly, the existence of predators has the potential to promote the generation of defensive structures such as spines, which not only deter grazers but as well increase surface area thus reducing sinking rates (Nguyen et al., 2011). The potential to adjust defenses against grazers is well recognized (Vos et al., 2004) creating an evolutionary arms race (Smetacek, 2001) as predators also show the ability to respond to changing prey concentration (Mariani et al., 2013). The ability of planktonic organisms to react to increased predator or prey concentrations "increases the relative importance of bottom-up controls" (Vos et al., 2004) thus highlighting the role of physical processes.

Given the above considerations, in the following we present a conceptual model of the seasonal dynamics of phytoplankton in the North Atlantic. With this model we aspire to move toward a more holistic understanding of the different concepts discussed in the literature, highlighting the interplay between bio-physical mechanisms controlling the annual phytoplankton dynamics as well as integrating the cells ability to react to changes in environmental forcing.

\section{PULLING IT TOGETHER: A CONCEPTUAL MODEL OF SEASONAL DYNAMICS}

In the winter, the concentration of phytoplankton within the winter mixed layer is low and typically homogeneously distributed (Backhaus et al., 2003; Ward and Waniek, 2007), however the depth integrated standing stock is on the same order of magnitude as during the spring bloom (Backhaus et al., 2003; Behrenfeld, 2010). During this period Phyto-convection can maintain a viable 
phytoplankton stock (Backhaus et al., 2003). Phyto-convection has been defined as the ability of convective mixing to sustain a viable phytoplankton population within a deep mixed layer by counteracting cell sinking rates hence frequently returning them into the euphoric zone (Backhaus et al., 1999) (Figure 1B). Even though frequently exposed to the euphotic zone and not limited by nutrients during winter, low light levels during winter allow for limited photosynthesis, rendering the respiratory loss term proportionally more important (Sakshaug et al., 1991). Within the winter phytoplankton community a number of processes both physiological and morphological act to determine the composition of the surviving community. The sinking rates of non or slow growing cells have been found to be higher than those of blooming cells (Waite et al., 1992; Acuña et al., 2010). Thus, species, which are low light acclimatized, have the potential to exhibit reduced sinking rates and a greater potential to remain in the deep convective cells. Conversely, cell respiration is reduced relative to fast growing cells (Geider and Osborne, 1989; McMinn and Martin, 2013). Hence, although faster growing cells are favored due to reduced sinking rates, prolonged periods without exposure to light will result in losses due to higher respiration. Micro-zooplankton grazing has been identified as a key control on phytoplankton biomass (e.g., Banse, 1992; Sherr and Sherr, 2002) with changes in importance over the annual cycle. During winter, mixed layer deepening dilutes phytoplankton cells and active grazers resulting in the Decoupling of grazing pressure from specific phytoplankton growth $(\mu)$ (Evans and Parslow, 1985) (Figure 1C). Therefore, the combined effect of low grazing pressure, low cell respiration and convective mixing are able to compensate for cell sinking and limited light exposure, allowing for a low but positive net phytoplankton growth in the convective mixed layer. As a result, this leads to a slowly increasing standing stock, while the volumetric phytoplankton concentration due to the dilution of the mixed layer stays constant or even may decrease (Backhaus et al., 2003; Behrenfeld and Boss, 2014).

Additionally the ephemeral nature of deep convention can result in periods of reduced turbulence, due to a reduced net surface heat flux in conjunction with low wind stress. During these periods within the still actively mixed part of the upper ocean, levels of turbulence fall below the threshold of Critical Turbulence (Huisman et al., 1999) (Figure 1C). These periods of quiescence combined with the cells ability to control buoyancy (Waite et al., 1992; Acuña et al., 2010) can maintain cells in the surface layer. However, such events are short lived and therefore do not induce a density stratification of the water column, which enables phytoplankton cells to escape the grazing control of micro-zooplankton (Irigoien et al., 2005). Thus, without Recoupling with grazers, this can result in a light induced increase in growth and a subsequent surface bloom in the absence of stratification (Townsend et al., 1992) (Figure 1C). Furthermore, mesoscale ocean features such as eddies (Mahadevan et al., 2012) and fronts (Taylor and Ferrari, 2011a) can induce stratification in the absence of net positive

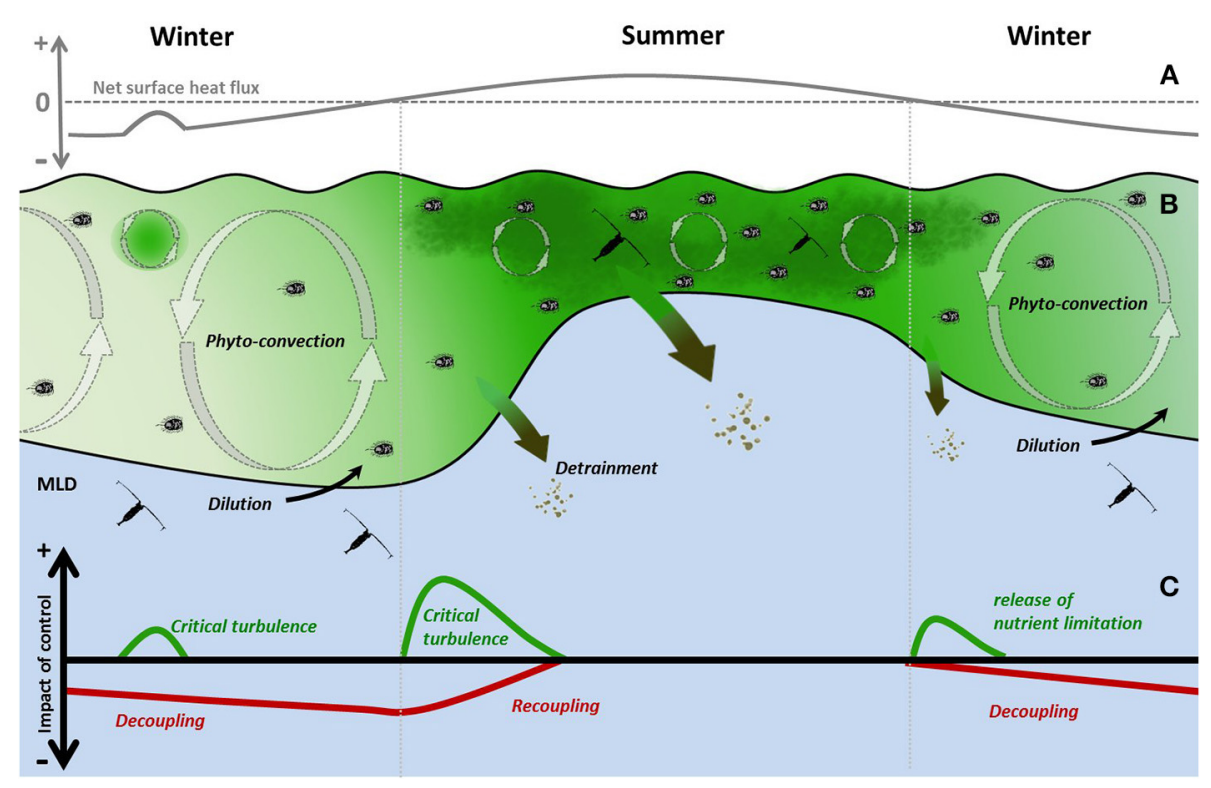

FIGURE 1 | Conceptual model of the physical and biological controls and their impacts on the seasonal cycle of phytoplankton in the open subarctic North Atlantic. (A) Net surface heat flux (B) During winter, mixed layer deepening causes the Dilution of plankton leading to a Decoupling of grazers from phytoplankton. During this period phytoplankton are sustained by Phyto-convection and in combination with ephemeral periods of Critical Turbulence result in positive net growth. In early spring the shutdown of deep convection leads to a light driven increase in surface growth. Subsequently re-stratification results in further enhanced growth conditions, i.e., the Critical Depth Model; the Detrainment of phytoplankton below the surface mixed layer; and a Recoupling with grazers, resulting in a close coupling of biotic and abiotic controls to mixed layer dynamics as observed during summer. In autumn the releases of nutrient limitation due to mixed layer deepening lead to specific growth controlled period before returning to winter conditions. Meso-zooplankton (symbolized by copepods) remain in diapause below the convective mixed layer during winter and migrate into the surface $M L$ in spring. (C) Difference of the impact of abiotic (green) and biotic (red) controlling mechanisms on net phytoplankton growth $(r)$ relative to the equilibrium dynamics imposed by phytoplankton composition and mixed layer. 
heat input, leading to conditions conducive for phytoplankton growth. In the spring, it has been suggested that the initiation of "blooms can begin following winter deep convection, and prior to the vernal development of stratification" (Townsend et al., 1994). Following the "Convection-Shutdown-Hypothesis" (Ferrari et al., 2014) during this transitional stage, positive net surface heat flux (Figure 1A) leads to the shutdown of deep convection. Stratification does not occur instantaneously resulting in a non-homogeneous mixing throughout the density defined mixed layer (Marshall and Schott, 1999; Taylor and Ferrari, 2011b). Within the upper actively mixed component, turbulence below the threshold of Critical Turbulence (Huisman et al., 1999) occurs, thus creating favorable light conditions for a further increase in cell growth. Under conditions of increased cell growth $(\mu)$, respiration rates are higher (Falkowski and Owens, 1980; Xue et al., 1996), while the species-specific sinking rates (Waite et al., 1992) decrease and cells may even achieve positive buoyancy (Acuña et al., 2010). This represents a switch in the strength of physiologically driven loss terms, when compared to winter conditions. This change has the potential to be of considerable advantage for cells. Increased light exposure due to the seasonal increase in light and lower mixing depth allows for a higher photosynthetic yield, while the reduction in turbulent mixing increases the impact of cell sinking which is potentially offset by the cells ability to reduce sinking rates. Here, similar to windows of reduced convective mixing in winter, the increase in light exposure, facilitated by adjustment of the physiologically controlled phytoplankton loss rates, allows the increase in specific phytoplankton growth rate. Simultaneously, Recoupling with micro-zooplankton gradually increases grazing pressure as stratification sets in. However, during the initial stage after the shutdown of deep convection light-driven phytoplankton growth out-completes the increase in grazing control, thus leading to a further increase in net phytoplankton growth and biomass concentration near the surface (Townsend et al., 1992; Taylor and Ferrari, 2011b).

Furthermore, the reduction of convective mixing and the subsequent shoaling of the mixed layer causes the Detrainment of phytoplankton cells below the receding convective layer (Evans and Parslow, 1985; Behrenfeld and Boss, 2014), leaving cells to sink to depth below the retreating mixed layer (Figure 1B). With respect to the integrated phytoplankton biomass within the mixed layer, the increase in surface concentration is compensated by the Detrainment of cells at greater depth, resulting in a standing stock on the same order of magnitude (Backhaus et al., 2003; Behrenfeld and Boss, 2014). Subsequently, when surface mixing becomes shallower than the euphotic zone phytoplankton dynamics follow the traditional "Critical-Depth-Hypothesis" where a combination of mixed layer depth, light availability, and grazing pressure determines net phytoplankton growth and volumetric concentration (Sverdrup, 1953; Banse, 1992). Noteworthy, in the North Atlantic the bulk of the meso-zooplankton community spend the winter in diapause below the permanent mixed layer (Heinrich, 1962), thus removing their grazing pressure independent of mixed layer dynamics. Behrenfeld and Boss (2014) argue that the role of meso-zooplankton has traditionally been overestimated, but despite more recent findings highlighting the importance of micro-zooplankton (e.g., Banse, 1992), meso-zooplankton still form an important part of the grazing community during spring and early summer. Over the summer, zooplankton grazing, dominated by micro-zooplankton grazing (Banse, 1992) and viral infection (Suttle, 2005), in combination with nutrient limitation, control phytoplankton growth and regulate the collapse and accession of the different phytoplankton groups (Margalef, 1978; Martin, 2012). Species-specific blooms are often reported to be terminated by nutrient limitation, which may induced increased sinking rates. These can lead to the rapid removal of cells from the mixed layer, resulting in carbon export events as has been prominently observed for diatom blooms (Allen et al., 2005). During fall, surface cooling results in a deepening of the pycnocline and an injection of nutrient rich water into the nutrient depleted surface layer as well as a reduction in grazing pressure due to dilution (Sommer et al., 2012; Behrenfeld and Boss, 2014). Both these processes lead to an increase in net phytoplankton growth and can result in an autumn bloom, which potentially terminates with a carbon export event (Findlay et al., 2005). Thereafter the system reverts to winter conditions as described by the "Disturbance-Recovery-Hypothesis."

\section{PHYTOPLANKTON DYNAMICS IN A CHANGING WORLD}

Unlike subtropical systems, which are relatively stable and dominated by nutrient limitation and the microbial loop (e.g., Sherr and Sherr, 2002) or the more recently identified mixotrophic loop (Mitra et al., 2014) throughout the year, the North Atlantic shows distinct changes over the season. Here, the physical controls shift from light limitation in autumn and winter to nutrient controls during the summer, while the grazing control decreases during the winter and due to Recoupling of micro-zooplankton (Behrenfeld, 2010) and the re-emergence meso-zooplankton form diapause (Heinrich, 1962; Sommer et al., 2012) increase sharply in spring. Critical for the North Atlantic phytoplankton community will be the influence of climate change on the processes influencing the winter community and the seed population for the spring bloom. Climate change is expected to increase stratification in winter, which has been proposed to have opposing effects on phytoplankton dynamics. Stratification will reduce the dilution of active zooplankton and thus increase grazing pressure (Behrenfeld et al., 2013) while also reducing light limitation of phytoplankton growth (Doney, 2006) potentially leading to higher biomass. A reduction of net surface heat flux will impact upon the timing of occurrence and retreat, the depth as well as the degree of deep convective mixing thereby impacting on the phytoplankton community. During summer, a greater density difference between the surface and deep layers will reduce the flux of nutrients into the euphotic zone thereby reducing production. As a result the North Atlantic ecosystem is likely to become more similar to lower latitude oligotrophic ecosystems as it moves closer toward a recycling dominated community (Doney, 2006). In the North Atlantic the complex interplay between abiotic and biotic controls on phytoplankton clearly renders our understanding of the impact of climate change anything but straightforward. Given the central role of phytoplankton in marine ecosystems, e.g., in the North Atlantic, moving toward a more integrated approach for understanding and predicting the 
role phytoplankton in the future is critical. Lewandowska et al. (2014) investigated the combined effects of biological and physical drivers on bloom dynamics focusing on mesocosm experiments and a global modeling approach. They concluded that "the effect of ocean warming on marine plankton depends on the nutrient regime," and thus stratification. However, the temperature dependent growth rate of heterotrophic protists shows a stronger increase than that of phytoplankton. Thus, a scenario of increased temperature could also lead to enhanced trophic coupling, increasing grazing control (Rose and Caron, 2007). In a recent model study Ward et al. (2014) found the total biomass to be depended on nutrient availability, while grazing had a bigger impact on community structure.

Our conceptual model is by no means complete as for example, spatial and temporal small-scale variability of the processes outlined will determine local phytoplankton features. Furthermore, an enhanced understanding on the role of viruses (Suttle, 2005), cellular respiration (Marra, 2009), the adaptive capacities of organisms as well as new insights on the interaction between biophysical processes will continue to modify our perception of phytoplankton dynamics in this ecosystem.

\section{ACKNOWLEDGMENTS}

We are thankful to Mark Payne, Adrian Martin, Richard Bellerby, and Artur Palacz for useful comments on an earlier version of the manuscript, fruitful discussions with the participants of the FS Meteor "Deep convection" cruise funded by the Deutsche Forschunggemeinschaft as well the constructive comments of the reviewers how helped to improve this manuscript substantially. Partial financial support was provided by the FP7 program EURO-BASIN (Contract Nr. 264933).

\section{REFERENCES}

Acuña, J., López-Alvarez, M., Nogueira, E., and González-Taboada, F. (2010). Diatom flotation at the onset of the spring phytoplankton bloom: an in situ experiment. Mar. Ecol. Prog. Ser. 400, 115-125. doi: 10.3354/meps08405

Allen, J. T., Brown, L., Sanders, R., Moore, C. M., Mustard, A., Fielding, S., et al. (2005). Diatom carbon export enhanced by silicate upwelling in the northeast Atlantic. Nature 437, 728-732. doi: 10.1038/nature03948

Anderson, L., and Sweeney, B. (1977). Diel changes in sedimentation characteristics of Ditylum brightwelli: changes in cellular lipid and effects of respiratory inhibitors and ion-transport modifiers. Limnol. Oceanogr. 22, 539-552. doi: 10.4319/lo.1977.22.3.0539

Backhaus, J., Hegseth, E., Wehde, H., Irigoien, X., Hatten, K., and Logemann, K. (2003). Convection and primary production in winter. Mar. Ecol. Prog. Ser. 251, 1-14. doi: 10.3354/meps251001

Backhaus, J., Wehde, H., Hegseth, E., and Kämpf, J. (1999). Phyto-convection:the role of oceanic convection in primary production. Mar. Ecol. Prog. Ser. 189, 77-92. doi: 10.3354/meps189077

Banse, K. (1992). "Grazing, temporal changes of phytoplankton concentrations, and the microbial loop in the open sea," in Primary Productivity and Biogeochemical Cycles in the Sea Sea Environmental Science Research, Vol. 43, eds P. G. Falkowski and A. D. Woodhead (New York, NY: Plenum Press), 409-440.

Behrenfeld, M. J. (2010). Abandoning Sverdrup's critical depth hypothesis on phytoplankton blooms. Ecology 91, 977-989. doi: 10.1890/09-1207.1

Behrenfeld, M. J., and Boss, E. S. (2014). Resurrecting the ecological underpinnings of ocean plankton blooms. Ann. Rev. Mar. Sci. 6, 167-194. doi: 10.1146/annurev-marine-052913-021325

Behrenfeld, M. J., Doney, S. C., Lima, I., Boss, E. S., and Siegel, D. A. (2013). Annual cycles of ecological disturbance and recovery underlying the subarctic Atlantic spring plankton bloom. Global Biogeochem. Cycles 27, 526-540. doi: $10.1002 / g b c .20050$
Bienfang, P., Harrison, P., and Quarmby, L. (1982). Sinking rate response to depletion of nitrate, phosphate and silicate in four marine diatoms. Mar. Biol. 67, 295-302. doi: 10.1007/BF00397670

Bowler, C., and Scanlan, D. J. (2014). Genetics. Being selective in the Prochlorococcus collective. Science 344, 366-367. doi: 10.1126/science.1253817

Brookes, J., and Ganf, G. (2001). Variations in the buoyancy response of Microcystis aeruginosa to nitrogen, phosphorus and light. J. Plankton Res. 23, 1399-1411. doi: 10.1093/plankt/23.12.1399

Chiswell, S. (2011). Annual cycles and spring blooms in phytoplankton: don't abandon Sverdrup completely. Mar. Ecol. Prog. Ser. 443, 39-50. doi: 10.3354/meps09453

Doney, S. C. (2006). Plankton in a warmer world. Nature 444, 695-696. doi: $10.1038 / 444695 a$

Evans, G., and Parslow, J. (1985). A model of annual plankton cycles. Biol. Oceanogr. 3, 327-347. doi: 10.1080/01965581.1985.10749478

Falkowski, P., and Owens, T. (1980). Light-shade adaptation two strategies in marine phytoplankton. Plant Physiol. 66, 592-595. doi: 10.1104/pp.66.4.592

Ferrari, R., Merrifield, S. T., and Taylor, J. R. (2014). Shutdown of convection triggers increase of surface chlorophyll. J. Mar. Syst. doi: 10.1016/j. jmarsys.2014.02.009. Available online at: http://www.sciencedirect.com/ science/article/pii/S0924796314000384

Findlay, H. S., Yool, A., Nodale, M., and Pitchford, J. W. (2005). Modelling of autumn plankton bloom dynamics. J. Plankton Res. 28, 209-220. doi: 10.1093/plankt/fbil14

French, F., and Hargraves, P. (1980). Physiological characteristics of plankton diatom resting spores. Mar. Biol. Lett. 1, 185-195.

Geider, R. J., and Osborne, B. A. (1989). Respiration and microalgal growth: a review of the quantitative relationship between dark respiration and growth. New Phytol. 112, 327-341. doi: 10.1111/j.1469-8137.1989.tb00321.x

Gruber, N., Keeling, C. D., and Bates, N. R. (2002). Interannual variability in the North Atlantic Ocean carbon sink. Science 298, 2374-2378. doi: 10.1126/science. 1077077

Heinrich, A. K. (1962). The life histories of plankton animals and seasonal cycles of plankton communities in the oceans. J. Cons. Int. Explor. Mer. 27, 15-24. doi: 10.1093/icesjms/27.1.15

Huisman, J., Arrayás, M., Ebert, U., and Sommeijer, B. (2002). How do sinking phytoplankton species manage to persist? Am. Nat. 159, 245-254. doi: $10.1086 / 338511$

Huisman, J., Oostveen, P., van, and Weissing, F. (1999). Critical depth and critical turbulence: two different mechanisms for the development of phytoplankton blooms. Limnol. Oceanogr. 44, 1781-1787. doi: 10.4319/lo.1999.44. 7.1781

Irigoien, X., Flynn, K. J., and Harris, R. P. (2005). Phytoplankton blooms: a "loophole" in microzooplankton grazing impact? J. Plankton Res. 27, 313-321. doi: 10.1093/plankt/fbi011

Jochem, F. (1999). Dark survival strategies in marine phytoplankton assessed by cytometric measurement of metabolic activity with fluorescein diacetate. Mar. Biol. 135, 721-728. doi: 10.1007/s002270050673

Körtzinger, A., Send, U., Lampitt, R. S., Hartman, S., Wallace, D. W. R., Karstensen, J., et al. (2008). The seasonal p CO 2 cycle at $49^{\circ} \mathrm{N} / 16.5^{\circ} \mathrm{W}$ in the northeastern Atlantic Ocean and what it tells us about biological productivity. J. Geophys. Res. 113, C04020. doi: 10.1029/2007JC004347

Landry, M. R., and Hassett, R. P. (1982). Estimating the grazing impact of marine micro-zooplankton. Mar. Biol. 67, 283-288. doi: 10.1007/BF00397668

Lewandowska, A. M., Boyce, D. G., Hofmann, M., Matthiessen, B., Sommer, U., and Worm, B. (2014). Effects of sea surface warming on marine plankton. Ecol. Lett. 17, 614-623. doi: 10.1111/ele.12265

Mahadevan, A., D’Asaro, E., Lee, C., and Perry, M. J. (2012). Eddy-driven stratification initiates North Atlantic spring phytoplankton blooms. Science 337, 54-58. doi: 10.1126/science. 1218740

Margalef, R. (1978). Life-forms of phytoplankton as survival alternatives in an unstable environment. Oceanol. acta 1, 493-509.

Mariani, P., Andersen, K. H., Visser, A. W., Barton, A. D., and Kiørboe, T. (2013). Control of plankton seasonal succession by adaptive grazing. Limnol. Oceanogr. 58, 173-184. doi: 10.4319/lo.2013.58.1.0173

Marra, J. (2009). Net and gross productivity: weighing in with 14C. Aquat. Microb. Ecol. 56, 123-131. doi: 10.3354/ame01306

Marshall, J., and Schott, F. (1999). Open ocean convection: observations, theory, and models. Rev. Geophys. 37, 1-64. doi: 10.1029/98RG02739 
Martin, A. (2012). The seasonal smorgasbord of the seas. Science 337, 46-47. doi: 10.1126/science. 1223881

McMinn, A., and Martin, A. (2013). Dark survival in a warming world. Proc. R. Soc. B Biol. Sci. 280:20122909. doi: 10.1098/rspb.2012.2909

Miklasz, K., and Denny, M. (2010). Diatom sinking speeds: improved predictions and insight from a modified Stokes' law. Limnol. Oceanogr. 55, 2513-2525. doi: 10.4319/lo.2010.55.6.2513

Mitra, A., Flynn, K. J., Burkholder, J. M., Berge, T., Calbet, A., Raven, J. A., et al. (2014). The role of mixotrophic protists in the biological carbon pump. Biogeosciences 11, 995-1005. doi: 10.5194/bg-11-995-2014

Nguyen, H., Karp-Boss, L., Jumars, P. A., and Fauci, L. (2011). Hydrodynamic effects of spines: a different spin. Limnol. Oceanogr. Fluids Environ. 1, 110-119. doi: 10.1215/21573698-1303444

Riebesell, U., Schulz, K. G., Bellerby, R. G. J., Botros, M., Fritsche, P., Meyerhöfer, M., et al. (2007). Enhanced biological carbon consumption in a high CO2 ocean. Nature 450, 545-548. doi: 10.1038/nature06267

Rose, J., and Caron, D. (2007). Does low temperature constrain the growth rates of heterotrophic protists? Evidence and implications for algal blooms in cold waters. Limnol. Oceanogr. 52, 886-895. doi: 10.4319/lo.2007.52.2.0886

Sakshaug, E., Johnsen, G., Andresen, K., and Vernet, M. (1991). Modeling of light-dependent algal photosynthesis and growth: experiments with the Barents sea diatoms Thalassiosira nordenskioldii and Chaetoceros furcellatus. Deep Sea Res. Part A. Oceanogr. Res. Pap. 38, 415-430. doi: 10.1016/0198-0149(91) 90044-G

Sherr, E. B., and Sherr, B. F. (2002). Significance of predation by protists in aquatic microbial food webs. Antonie Van Leeuwenhoek 81, 293-308. doi: 10.1023/A:1020591307260

Smayda, T. (1970). The suspension and sinking of phytoplankton in the sea. Oceanogr. Mar. Biol. Annu. Rev. 8, 353-414.

Smayda, T. J. (1997a). Harmful algal blooms: their ecophysiology and general relevance to phytoplankton blooms in the sea. Limnol. Oceanogr. 42, 1137-1153. doi: 10.4319/lo.1997.42.5_part_2.1137

Smayda, T. J. (1997b). What is a bloom? A commentary. Limnol. Oceanogr. 42, 1132-1136. doi: 10.4319/lo.1997.42.5_part_2.1132

Smetacek, V. (2001). A watery arms race. Nature 411, 745. doi: 10.1038/35081210

Smetacek, V., and Passow, U. (1990). Spring bloom initiation and Sverdrup's critical-depth model. Limnol. Oceanogr. 35, 228-234. doi: 10.4319/lo.1990.35. 1.0228

Sommer, U., Adrian, R., De Senerpont Domis, L., Elser, J. J., Gaedke, U., Ibelings, B., et al. (2012). Beyond the Plankton Ecology Group (PEG) model: mechanisms driving plankton succession. Annu. Rev. Ecol. Evol. Syst. 43, 429-448. doi: 10.1146/annurev-ecolsys-110411-160251

Sommer, U., Gliwicz, Z. M., Lampert, W., and Duncan, A. (1986). The PEG-model of seasonal succession of planktonic events in fresh waters. Arch. Hydrobiol. 106, 433-471.

Steenmann Nielsen, E., and Hansen, V. (1959). Measurements with the carbon-14 technique of the respiration rates in natural populations of phytoplankton. Deep Sea Res. 222-233. doi: 10.1016/0146-6313(58)90015-7
Suttle, C. A. (2005). Viruses in the sea. Nature 437, 356-361. doi: 10.1038/nature 04160

Sverdrup, H. (1953). On conditions for the vernal blooming of phytoplankton. J. Cons. 18, 287-295. doi: 10.4319/lom.2007.5.269

Taylor, J. R., and Ferrari, R. (2011a). Ocean fronts trigger high latitude phytoplankton blooms. Geophys. Res. Lett. 38, L23601. doi: 10.1029/2011GL049312

Taylor, J. R., and Ferrari, R. (2011b). Shutdown of turbulent convection as a new criterion for the onset of spring phytoplankton blooms. Limnol. Oceanogr. 56, 2293-2307. doi: 10.4319/lo.2011.56.6.2293

Townsend, D., Keller, M., Sieracki, M., and Ackleson, S. (1992). Spring phytoplankton blooms in the absence of vertical water column stratification. Nature 360, 59-62. doi: 10.1038/360059a0

Townsend, D. W., Cammen, L. M., Holligan, P. M., Campbell, D. E., and Pettigrew, N. R. (1994). Causes and consequences of variability in the timing of spring phytoplankton blooms. Deep Sea Res. Part I Oceanogr. Res. Pap. 41, 747-765. doi: 10.1016/0967-0637(94)90075-2

Vos, M., Verschoor, A., and Kooi, B. (2004). Inducible defenses and trophic structure. Ecology 85, 2783-2794. doi: 10.1890/03-0670

Waite, A. M., Thompson, P. A., and Harrison, P. J. (1992). Does energy control the sinking rates of marine diatoms? Limnol. Oceanogr. 37, 468-477. doi: 10.4319/lo.1992.37.3.0468

Ward, B. A., Dutkiewicz, S., and Follows, M. J. (2014). Modelling spatial and temporal patterns in size-structured marine plankton communities: top-down and bottom-up controls. J. Plankton Res. 36, 31-34. doi: 10.1093/plankt/fbt097

Ward, B., and Waniek, J. (2007). Phytoplankton growth conditions during autumn and winter in the Irminger Sea, North Atlantic. Mar. Ecol. Prog. Ser. 334, 47-61. doi: 10.3354/meps334047

Xue, X., Gauthier, D. A., Turpin, D. H., and Weger, H. G. (1996). Interactions between photosynthesis and respiration in the green alga chlamydomonas reinhardtii (characterization of light-enhanced dark respiration). Plant Physiol. 112, 1005-1014. doi: 10.1104/pp.112.3.1005

Conflict of Interest Statement: The authors declare that the research was conducted in the absence of any commercial or financial relationships that could be construed as a potential conflict of interest.

Received: 20 May 2014; accepted: 18 August 2014; published online: 04 September 2014.

Citation: Lindemann C and St. John MA (2014) A seasonal diary of phytoplankton in the North Atlantic. Front. Mar. Sci. 1:37. doi: 10.3389/fmars.2014.00037

This article was submitted to Marine Ecosystem Ecology, a section of the journal Frontiers in Marine Science.

Copyright (c) 2014 Lindemann and St. John. This is an open-access article distributed under the terms of the Creative Commons Attribution License (CC BY). The use, distribution or reproduction in other forums is permitted, provided the original author(s) or licensor are credited and that the original publication in this journal is cited, in accordance with accepted academic practice. No use, distribution or reproduction is permitted which does not comply with these terms. 